\title{
Cost management at the tube-rolling enterprises
}

\author{
A.E. Shevelev ${ }^{1}$, E.A. Sheveleva ${ }^{1}$, and M.I. Bazhanova ${ }^{1, *}$ \\ ${ }^{1}$ South-Ural State University, Chelyabinsk, Russia
}

\begin{abstract}
The article is devoted to the problem of constructing an effective system of cost management of tube rolling enterprises. According to numerous studies for over the past few years tube-rolling consumption has increased inside domestic market. Despite of the positive trends, these enterprises still can't solve the problem of effective cost control, significantly affected their final financial results and, consequently, their competitiveness as a whole. The authors examined the legal aspects of the formation and recognition of enterprise's costs. Main approaches to cost classification of the main members are investigated. Main features of tube-rolling enterprises are analyzed and requirements to their cost management system structure are defined. A cost management model of tube-rolling industry as a logframe of consistent implementation stages, including corrections and feedback, is performed.
\end{abstract}

\section{Introduction}

At the moment enterprises of the metallurgical complex and their activity play significant role in the Russian economy. According to numerous modern studies over 28000 metallurgical enterprises operate in the domestic economy now. In general terms, this industry can be divided into nonferrous and ferrous metallurgy, last is of more value.

An important segment of ferrous metallurgy is tube-rolling industry. Such tube-rolling enterprises, as Nizhnytagilskiy tube-rolling plant "Metallinvest", Severskiy tube-rolling plant, Kamenskuralskiy tuberolling plant, Pervouralskiy novotrubniy plant, Uralskiy tube-rolling plant, Chelyabinskiy tuberolling plant, Pervouralskiy novotrubniy plant operate in Ural Federal District.

Currently, the demand for tube-rolling production is growing steadily. For example, the consumption of tubes grew by $6.8 \%$ at domestic market, considering that import decreased on average by $20 \%$ [1].

\section{Relevance}

Despite of positive trends tube-rolling enterprises have significant problems with effective cost management system forming. It is known that one of the sustainable economic growth factors is the ability of an enterprise to reduce costs, directly related to production and sale of finished products. Besides, complex production process in this sector, significantly determines the diversity and complexity costs and causes to their impact on the profitability of the activities undertaken. In this regard, maintenance of operative profitability through effective and continuous cost management process becomes of great value, it is undoubtedly of great relevance considering modern trends of financial and economic development.

\section{Mane problem}

Before turning to the problem of cost management effective system forming, we should identify the peculiarities of tube-rolling enterprises activity and main types of costs. There is no unified conceptual approach to the interpretation of the term "costs" in the economic literature. Often one can come across with the interpretation of this term, its rationale and composition in the connection with such categories as "spendings", "costs price" and "expenses". Consider the content of these terms in details.

International financial reporting standards name "costs" as consumed in production activity resources, which have not been recognized yet as expenses and recorded in the balance sheet at the end of the year as unfinished production, finished products, goods shipped [2].

In the Russian management theory and practice term "costs" is often identified with the term "expenses". For example, in the Tax Code of the Russian Federation [3] is not highlighted significant differences in the interpretation of these two categories. However, detailed study of this problem indicates a serious difference of these terms. PBU $10 / 99$ "expenses of organizations" provides the following definition of the term "expenses": "economic benefits decreasing as a result of the disposal of assets (monetary funds, other property) and (or) occurrence of obligations leading to reduction of capital of the organization, except for reduction of contributions upon decision of participants

Corresponding author: mbazhanova@mail.ru 
(proprietors of property)" [4]. Expenses include such items as production costs of sold products (works, services), wages of administrative staff, depreciation, rental cost, and losses [5]. Based on this we can conclude that "expenses" represent the costs of the defined time period, documental and economical justified, fully undergone their value on sold during this period production [6].

In addition to the interpretation of the term "expenses" according to PBU 10/99 (i. 9) the mechanism of transaction enterprise's expenses to the cost of the produced products (works, services). The cost price of goods manufactured (works, services) is formed on the basis of the following expenses of main types of activity:

- expenses recognized in the reporting and previous periods;

- expenses related to incomes of the following reporting periods, i.e. passing.

In general, cost price is total costs on production and sales of a particular enterprise expressed in monetary terms, which compensation is required for the simple reproduction [7]. Based on this, we can conclude that a significant difference of terms "costs" and "cost price" is manifested in the form of completion of the production and circulation processes. Costs are related to these processes, regardless of their completeness, as well as the nature of relationships with production and sale of products. The cost price implies the completeness of these processes.

General indicator of the number of considered terms is the term "spendings". It's interpretation is often based on the fact of limited resources and possibility of their alternative use. Spendings represent a real or hypothetical monetary measure of the aggregate financial resources used for certain purpose. On this basis, costs can be defined as the aggregate of enterprise's spendings at the moment of purchasing of any services, material values, etc. These costs cause to reducing of economic resources, or increasing accounts payable of an enterprise. In this regard, costs may be attributed either to the organization's assets (in the case of income in the future) or to liabilities (in the case of non-receipt of income in the future and, as a consequence, decrease of retained earnings of the company during the reporting period) [7].

Taking this into account, we may add to the concept of enterprise the following items [7]:

- costs are determined by using labor, material, financial resources, etc., reflecting their amount spent in the production and sales of products (works, services);

- the amount of resources used is expressed in natural and monetary units

- costs are related to the defined objectives of the enterprise;

- consumption of different types of resources must be economic justified by the conditions of the production process and aims of creating values in the production of goods (works, services);
- costs, finally, are transformed to the cost price of production (works, services).For a deeper study of the nature of costs and ways to manage them, it is necessary to make up their classification. Currently there are numerous of ways to classify costs in the economic literature. Consider the most popular of them.

Thus, Drury K [8], Karpova T. [9], propose the "aggregative" group, whereby all of the costs are divided into the following groups:

- costs, information of which is used for the purposes of regulation and control;

- costs used for decision-making and planning process;

- costs, information of which is used for calculation and evaluation of finished products.

- Paliy V. [10] offers the following classification according to:

- the degree of influence the volume of production: fixed and variable;

- the process for assigning to the cost price: direct and overhead;

- the frequency of investments: current and nonrecurring;

- to the relation to the manufacturing process: production and non-production;

- the time calculation: planned and actual;

- the degree of aggregation: per unit of product and total.

Lastovetskiy V.E. [11] as the classifications allocates production factors and appointment of certain types of expenses in relation to the nature of resource consumption. These classification features can provide the basis for cost management and calculation of production costs.

Sokolov Y.V. [7] proposed the following grouping of costs according to:

- the type of economic life factors: the cost of activities and events;

- the recognition: accrued and paid;

- the relation to money: monetary and non-monetary;

- the relation to the balance sheet: capitalized and non- capitalized;

- the expectation: ordinary and extraordinary;

- the evaluation: planning and regulatory.

The most correct costs classification in terms of their management were offered by Vakhrushina M.A., Gomonko E.A., Tarasova T.F. Consider these approaches in more detail.

Vakhrushina M.A. [12, 13] proposes to classify all the costs according to the purposes and objectives of management accounting (tab. I).

Professor Mizikovskiy E.A. [14] as the basis of classification of costs took an assumption about their depending upon types of activity of an enterprise (main and other). Generally all costs he proposes to group by economic elements and calculation items.

Efremova A. A. [15] proposed to classify the enterprise's costs according to a period, method of including to the cost price, economic structure, relation to production amount and efficiency. 
Table 1. Costs classification according to Vakhrushina.

\begin{tabular}{|c|c|}
\hline $\begin{array}{c}\text { Objectives of } \\
\text { management } \\
\text { accounting }\end{array}$ & Costs classification \\
\hline $\begin{array}{l}\text { calculation of } \\
\text { cost price of } \\
\text { goods } \\
\text { manufactured, } \\
\text { cost estimation } \\
\text { of reserves and } \\
\text { profits }\end{array}$ & $\begin{array}{l}\text { Incoming and pas } \\
\text { Direct and indirect } \\
\text { Basic and overhead } \\
\text { Production and periodic } \\
\text { Single and complex } \\
\text { Ongoing and one-time }\end{array}$ \\
\hline $\begin{array}{l}\text { decision making } \\
\text { and planning }\end{array}$ & $\begin{array}{l}\text { Conditionally-constant and } \\
\text { conditionally-variables } \\
\text { Accept and not accept } \\
\text { Irrecoverable costs } \\
\text { Imputed (lost profits) } \\
\text { Marginal and incremental } \\
\text { Planned and unplanned }\end{array}$ \\
\hline
\end{tabular}

Gomonko E.A. and Tarasova T.V. [7] as a basis of costs classification take the following characteristics: the method of including to cost price of production, composition (homogeneity), the elements, the degree of management, participation in profits and losses valuation, position of a particular enterprise, he coverage by the plan.

These approaches according to the specifics of the enterprise may be supplemented by the following classification:

- depending on the management functions: commercial, administrative and production costs;

- depending on the type of resources consumed: cost of labor, working capital and fixed assets);

- depending on the industry sector of the enterprise: costs of trade enterprises, catering companies, industrial enterprises, etc.;

- depending on the specifics of money circulation: costs of production, the sphere of circulation, etc.

In general terms, costs are the total amount of all available resources of the enterprise in monetary form, used for it's economic activity for a certain period. We can highlight the following feature of the costs, as a management object. Costs are in constant dynamics due to price changes of purchased resources, and the revision of the normative values of the expenditure coefficients.

The formation of an effective cost management system on any industrial enterprise is difficult without understanding the specifics of products, as well as the essence of production and sales processes.

Most tube-rolling enterprises produce the following range of products $[16,17,18,19]$ :

- welded straight-seam tubes (mainly tubes of large diameter);

- seamless tubes of OCTG;

- seamless industrial tubes etc.

Large diameter tubes used for oil and gas pipelines to transfer the hydrocarbons over long distances, and the transportation of crude oil and natural gas over shorter distances from wells to processing plants, storage tanks and loading and distribution of raw materials. OCTG used in oil and gas wells. They are divided into:
- casing pipes used in the drilling and operation of wells;

- pump-compressor pipe for oil and gas production, which are used for withdrawal of gas and oil to the surface;

- oil and gas transportation pipes that are used to transport oil and natural gas, etc.

Seamless industrial pipes are used in various industries. Their use is associated with the transportation of steam, water, gas and air under high pressure. These tubes are divided into hot-rolled, cold-formed, boilers, stainless, bearing, etc.

The described range of products is largely responsible for the specificity of activity of the tuberolling enterprises. Analysis of most famous enterprises allows to allocate a number of features with respect to different spheres and aspects of their activities.

As to the process of production tube-rolling enterprises have the following features:

- the exact division of the production process to the stages;

- limiting the possibility of establishing inventories of unfinished products at any stage of the process;

- unbreakable connection between the separate parts of the process;

- limited opportunities to interrupt the process;

- relatively long production cycle;

- within a single production plant a large number of nomenclature units is produced;

- presence of downtime due to the transition of production to another size ("handling");

- high demands on compliance with the quality of the finished product with GOST and TU;

- the need for a large number of units and the nomenclature of raw materials needed for production, and others.

In the field of economic and financial planning and accounting enterprises have the following peculiarities:

- raw materials which have been released to production are put off in accordance with standards established by the technical department, but not the requirements of GOST and TU;

- need of the planned and actual costing of finished goods;

- need to address the relationship of different structural units and departments forming a single production chain;

- when using the client's own blanks and blank ("tolling metal") planning process is carried out in different ways;

- distribution of general and ccommercial expenses directly proportional to the volumes of production;

- use of a large number of costing nomenclatures items;

- redistributive cost accounting (often not a separate department acts as a redistribution, and its production sites);

- when metal flow planning not only the return and irrecoverable loss, but also ingots (forgings, billets) 
required to adjust the mill and others should be taken into account.

In the management field often the strategy of outsourcing in relation to auxiliary and new types activities is used.

High need for the use of the process approach when making management decisions, as well as a rigid and rather high demands on the selection and maintenance of management personnel are characterized by. In addition, tube-rolling enterprises have often horizontal integration.

For example, currently on the territory of the Russian Federation such largest tube-rolling holdings, as "United metallurgical company", "Pipe metallurgical company", enterprises of group "Chelyabinsk tube-rolling plant", etc. operate.

Supply and marketing sphere also has a number of specific features:

- tube-rolling enterprises, as a rule, have its own sales network, with offices throughout Russia;

- significant fluctuations of the demand for manufactured products under the influence of macroeconomic factors;

- implementation of sales activities mainly in the business market;

- dependence of the pricing from the cost price of products;

- need for monthly purchase of large quantities of various raw materials, etc.

Based on this, and on monitoring of practical sphere, we may name the following specific features, which play a crucial role in the formation of costs at the tube rolling enterprises:

- tube rolling enterprises have complex and organizational structure involving large number of units, in "head" company and in those, which operate according to principles of the strategy of outsourcing - the existence of forced technological downtime due to the transition of production to another size, a fairly long production cycle, as well as limiting the possibility of creating inventories of work in progress at any technological stage;

- no valuation costs from the perspective of the requirements of GOST and TU, and the lack of any standards when dealing with "tolling" metal;

- developed system application of costing items due to the use of a large amount of inventory items raw materials and other inventory items in the tube-rolling production;

- implementation of management cost accounting mainly by redistribution method;

- presence of both revocable and irrevocable losses, and ingots (forgings, billets) required for mill setup.

\section{Solution}

The basis of cost management system forming should include [20, 21]:

- need of a comprehensive approach to the management accounting system formation, affecting absolutely all structural units of the enterprise (holding);

- need of using resource approach, to use all available enterprise's resources in a proper way;

- need to use only quantitative indicators, which calculation is based on available and reliable information, to determine the current status and the future of the cost management system;

- formation of developed system of monitoring and internal control at various stages of cost management; - orientation to the various factors controlling impact, as well as external signals.

Considering the information obtained earlier, the following model of cost management system of the enterprise of tube-rolling industry is offered (Fig. 1).

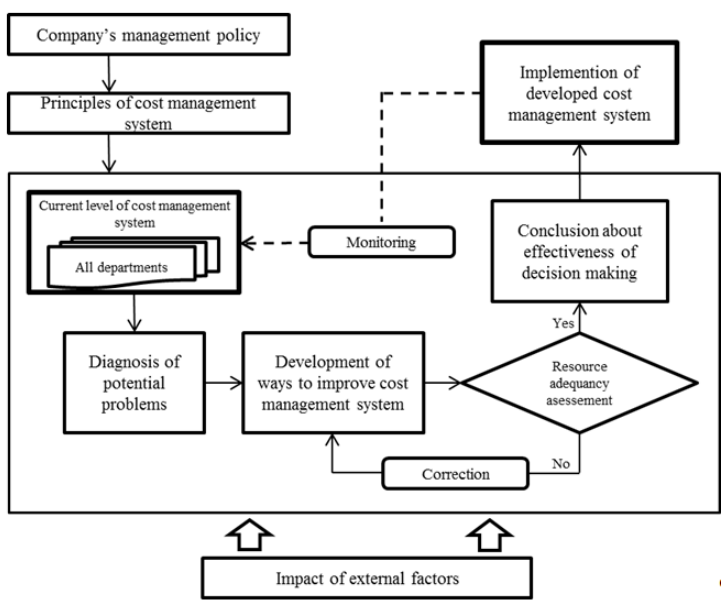

Fig. 1. Cost management model of tube-rolling enterprises.

This model of cost management system of tuberolling enterprise reflects the sequence of stages of its formation, taking into account the feedback that allows to adjust earlier decisions.

It allows to satisfy all the demands made earlier to the concept of cost management system of tuberolling enterprise. It should be noted that the implementation of each phase of the proposed model is the subject of a separate research.

Thus, the proposed model, which is a log frame consistent implementation stages, taking into account adjustments and feedback allows making correct management decisions about cost management of an enterprise and quantify the various stages of the implementation of the chosen strategy. This will allow to tube-rolling enterprises operate more efficiently than its competitors.

The work was supported by Act 211 Government of the Russian Federation, contract № 02.A03.21.0011

\section{References}

1. http://utmagazine.ru/posts/10561-ekonomikarossii-cifry-i-fakty-chast-8-metallurgiya.

2. International financial reporting standards (SPS Consultant-plus) 
3. Tax Code of Russian Federation - part two (2000, no. 117-FZ. SPS Garant)

4. PBU "Expenses of organizations" (no. 10/99 SPS Garant)

5. M.A. Vakhrushina, Management accounting: Textbook (Oмega-L, Moscow, 2006)

6. P.P. Taburchaka, Enterprise economy: textbook for high schools (Fenix, Rostov-on-Don, 2002)

7. Е.A. Gотопко, Cost management at the enterprise: textbook (KNORUS, Moscow, 2009)

8. K. Druri, Introduction to management and cost accountingi (Audi, Moscow, 1994)

9. T.P. Karpova, Management accounting: textbook for high schools (UNITI, Moscow, 2003)

10. V.F. Paliy, Management accounting of costs and incomes: with elements of financial accounting (INFRA-M, Moscow, 2009)

11. V.E. Lastovetskiy, Cost accounting for factors of production and centers of responsibility (Finance and Statistics, Moscow, 1988)
12. M.A. Vakhrushina, Management analysis: textbook for high schools (Омega-L, Moscow, 2008)

13. M.A. Vakhrushina, Management accounting: from theory to contemporary practice: textbook (Rossiyskaya gazeta, Moscow, 2005)

14. E.A. Mizikovskiy, Productive accounting (INFRA-M, Moscow, 2010)

15. A.A. Efremova, Cost price: from management accounting to cost accounting cost accounting (Vershina, Moscow, 2006)

16. http://kutzmet.ru.

17. https://stz.tmk-group.ru.

18. https://sintz.tmk-group.ru.

19. http://www.chelpipe.ru/for_clients/steel_pipes.

20. V.V. Alekseev, Metallurgy of the Urals from ancient times to our days (Nauka, Moscow, 2008)

21. V.V. Zapariy, The history of ferrous metallurgy of the Urals: the 90 years of the 20th century (Nauka, Moscow, 2003) 